V prvem delu prispevka avtor analizira pojav režiserja in spremembe njegovega položaja v slovenskem gledališču od druge polovice 19. stoletja do danes. $V$ tem kontekstu ga še posebej zanimajo premene gledališke režije, ki so se zgodile v drugi polovici 20. stoletja s pojavom skupinskega gledališča. Avtor metodološko kombinira zgodovinsko in primerjalno analizo, saj ti procesi potekajo še danes, ko se čedalje pogosteje govori in piše o »snovalnem gledališču« in drugih oblikah gledališkega ustvarjanja, ki se oddaljujejo od konvencionalnega postopka, po katerem dramatik napiše dramsko besedilo kot literarno umetnino, režiser pa jo prevede v gledališko umetnino. V sodobnem slovenskem gledališču je vse več predstav, kjer vnaprej napisano dramsko besedilo ni ključno za končni produkt ustvarjalnega procesa. Najpogosteje uporabljana izraza, ki označujeta to vrsto predstav, sta »po motivih« in »avtorski projekt«. Čeprav izraza nista sinonima in ju ni mogoče enačiti, oba implicirata tako imenovani »snovalni« tip gledališča. Avtor primerja skupinsko s snovalnim načinom ustvarjanja in opozori, da gre za praksi, ki sicer lahko potekata vzporedno, vendar ju ne moremo enačiti. Premislek o razmerju med skupinskim in snovalnim v sodobnem gledališču zgosti v ugotovitvi, da je za skupinsko gledališče konstitutivno specifično razmerje med ustvarjalno skupino in pozicijo režiserja, medtem ko je za snovalno gledališče ključno razmerje med ustvarjalno skupino in pozicijo dramatika. Na koncu se dotakne tudi povezav med postdramskim in postrežijskim gledališčem ter pojava ustvarjalne skupine kot kolektivne subjektivitete.

Ključne besede: slovensko gledališče, skupinsko ustvarjanje, snovalno gledališče, eksperimentalno gledališče, režijsko gledališče, postrežijsko gledališče

Aldo Milohnić je izredni profesor na Akademiji za gledališče, radio, film in televizijo Univerze v Ljubljani, kjer predava zgodovino gledališča. Od leta 2013 je predstojnik Centra za teatrologijo in filmologijo UL AGRFT. Je urednik številnih zbornikov in tematskih številk kulturnih časopisov, soavtor več knjig, avtor številnih znanstvenih in strokovnih člankov ter znanstvenih monografij Teorije sodobnega gledališča in performansa (2009), Umetnost v času vladavine prava in kapitala (2016) in Gledališče upora (2021).

aldo.milohnic@guest.arnes.si 


\section{O skupinskem in snovalnem ustvarjanju v slovenskem gledališču}

Aldo Milohnić

AGRFT Univerze v Ljubljani

Ko je kmalu po drugi svetovni vojni Narodna vlada Slovenije ustanovila današnjo Akademijo za gledališče, radio, film in televizijo, se je imenovala Akademija za igralsko umetnost. Tudi danes se igralska umetnost občasno pojavlja kot sopomenka za gledališko umetnost ali kar gledališče. V Gledališkem terminološkem slovarju je gledališče opredeljeno kot »dejavnost, pri kateri igralci in drugi nastopajoči igrajo vloge, prikazujejo (fiktivno) dramsko zgodbo, delujejo in se izražajo s svojim telesom pred neposredno navzočimi, sodelujočimi gledalci« (69-70). Slovarska definicija pojma »gledališče« torej temelji na igralcu in tudi drugih nastopajočih (v novejšem času se pogosto uporablja tudi angleška beseda »performerji ), ki jih posebej ne imenuje, saj bi bil seznam predolg. Igralci so gotovo differentia specifica gledališke umetnosti, a kljub temu ne moremo mimo dejstva, da so nastopajoči le najbolj izpostavljeni, najbolj vidni segment gledališkega dogodka, za katerim, poleg njih, navadno stoji še veliko drugih soustvarjalcev: dramaturgi, režiserji, scenografi, kostumografi itn. Zato pogosto slišimo, da je gledališče »kolektivna umetnost« ali, kot pravi Eugenio Barba, »situacija organiziranega prikazovanja« (28). Gledališka predstava torej nastane kot organizirana dejavnost skupine ljudi, v kateri najdemo različne specializirane poklice, od umetniških do tehničnih (ali podpornih). Skupinska dinamika, ki se razvije pri tem »organiziranem prikazovanju«, pa je lahko zelo različna. V tem prispevku ${ }^{1}$ bom analiziral, kako se je ta dinamika spreminjala v slovenskem gledališču od druge polovice 19. stoletja do danes, pri tem pa bom pozoren zlasti na status režiserja. $V$ tem kontekstu me bodo še posebej zanimale premene gledališke režije, ki so se zgodile v drugi polovici 20. stoletja s pojavom skupinskega gledališča in potekajo še danes, ko se čedalje pogosteje govori in piše o »snovalnem gledališču«, »avtorskih projektih« in drugih oblikah gledališkega ustvarjanja, ki se oddaljuje od konvencionalnega postopka, po katerem dramatik napiše dramsko besedilo kot literarno umetnino, režiser pa jo prevede v gledališko umetnino.

1 Članek je nastal v okviru raziskovalnega programa Gledališke in medumetnostne raziskave P6-0376, ki ga financira Javna agencija za raziskovalno dejavnost Republike Slovenije iz državnega proračuna. 
Organizacija gledališkega pogona je bila od antičnega grškega in rimskega do srednjeveškega in renesančnega gledališča bolj ali manj v rokah njegovih neposrednih producentov, v starejšem času dramatikov, pozneje igralcev, v 19. in zlasti 20. stoletju pa režiserjev (prim. Pavis, Gledališki slovar 641, 642). Beseda »režija« se sicer pojavi že leta 1820, vendar pa kot gledališki pojem obstaja šele od druge polovice 19. stoletja. »V tem obdobju je postal režiser odgovorni ,odredbodajalec' predstave," razlaga Patrice Pavis. Pred tem sta se namreč „vodja predstave ali včasih glavni igralec poukvarjala s tem, da sta po vnaprej določenem kalupu izoblikovala predstavo. Režija je bila zvedena na rudimentarno tehniko razmestitve igralcev v prostoru (mizansceno)« $(631,632)$. Režiserji so sprva še skrbeli za organizacijo gledališke produkcije, pozneje, ko sta se nadaljevali diferenciacija in specializacija gledaliških poklicev, pa so se lahko omejili na vodenje neposrednega procesa nastajanja gledališke uprizoritve. Pavis meni, da si je prav s pojavom režije gledališka umetnost »pridobila domovinsko pravico kot avtonomna umetnost« (637). Do podobnega sklepa je prišel tudi Alain Badiou, ki trdi, da je s tem, ko je »izumilo pojem režije«, 20. stoletje postalo »stoletje gledališča kot umetnosti«. S pojavom režiserja sovpada sprememba tradicionalnega razmerja med besedilom in njegovim uprizarjanjem, saj "gledališče pomeni v 20. stoletju nekaj drugega kot igranje komadov«. Režiser je namreč tisto, »kar je bilo prej le postavitev predstave, preoblikoval v samostojno umetnost «, kot »mislec predstave« je vzpostavil neki vmesni prostor med pisateljsko in igralsko umetnostjo, prostor, iz katerega je bilo naposled možno »kompleksno razmišljanje o razmerju med tekstom, igro, prostorom in občinstvom « (58-59). V drugi polovici 20. stoletja so se tako začele pojavljati pregledne, sintetične knjige o režijskem gledališču. Nekateri teoretiki gledališča, ki delujejo v anglosaškem prostoru, so prepričani, da sta bili monografski študiji Edwarda Brauna The Director and the Stage (1982) ter Davida Bradbyja in Davida Williamsa Directors' Theatre (1988) pred vsemi drugimi, vendar pri tem, nemara zaradi nepoznavanja jezika, povsem spregledajo zgodnjo knjigo Borisa Senkerja Redateljsko kazalište. Izšla je namreč že leta 1977 kot prva knjiga v zagrebški gledališki knjižni zbirki Prolog, ki jo je urejal znani hrvaški dramatik Slobodan Šnajder, sicer tudi urednik istoimenske gledališke revije.

Tudi v slovenskem gledališču se je režiser pojavil v drugi polovici 19. stoletja, vendar se je zares uveljavil šele v 20. stoletju. V zgodnjem obdobju delovanja ljubljanskega Dramatičnega društva je za režijo skrbel Josip Nolli. Njegovo delo je nadaljeval Josip Gecelj, od leta 1886 pa Ignacij Borštnik. Po njegovem odhodu leta 1894 je skoraj vse dramske predstave do konca 19. stoletja režiral Rudolf Inemann. Kadrovske, finančne in prostorske kapacitete ljubljanskega gledališča v 19. stoletju so bile zelo omejene, zato je bila glavna naloga takratnih režiserjev, da so se predstave sploh zgodile, razvijanju subtilnejših režijskih prijemov pa ti časi niso bili naklonjeni. Takrat je bil 
režiser pravzaprav »odgovorni vodja« predstave, ki je moral poskrbeti predvsem za red in požarno varnost. Danes je videti nenavadno, če režiser režira več predstav enega gledališča v isti sezoni, v 19. stoletju pa je bilo povsem normalno, da je npr. od leta 1867 do leta 1875 Nolli poskrbel za režijo vseh predstav (razen ene) in je tako režiral skoraj 160 dramskih in še 30 opernih predstav (prim. Repertoar 15-29, 174176 in Koter 64). Borštnik in Inemann sta sicer nekoliko okrepila položaj režiserja, vendar sta bila tudi onadva še vedno ujeta v paradigmo »serijskega« režiranja. To se je nekoliko spremenilo $v$ začetku 20. stoletja, ko se je že začelo pojavljati nekaj več imen režiserjev $\mathrm{v}$ okviru ene gledališke sezone, obenem pa se je nadaljevala praksa, da so režijske naloge opravljali nekateri izkušenejši igralci. ${ }^{2}$ Čeprav se je ljubljansko gledališče le nekako otreslo dotedanje prakse »serijskega« režiranja, saj se je število režiserjev $v$ tem obdobju znatno povečalo, je bilo njihovo delo, kot pravi Dušan Moravec, zelo poenostavljeno: »kazali so igralcem, kje morajo nastopiti in kje oditi, aranžirali so skupinske prizore in določali rekvizite, zanemarjali pa delo z igralcem pri oblikovanju značajev in prirejanju enotnih, harmoničnih predstav« (Slovensko gledališče 153). Z drugimi besedami, v začetku 20. stoletja je bil »režiser na slovenskem odru (pa tudi še kje) predvsem ,usmerjevalec prometa', komaj še, v zelo skromnih razsežnostih, tolmač vlog « (234). ${ }^{3}$ Do občutnejšega utrjevanja položaja režiserja v slovenskem gledališču je tako prišlo šele po koncu prve svetovne vojne, takrat izidejo tudi prvi tehtnejši spisi o režiji, kot sta npr. »Moderna režija« Milana Skrbinška in »Vprašanje režiserjev v ljubljanski drami« Cirila Debevca. Takrat so sicer režiserji še vedno prihajali iz vrst igralcev, vendar se je vsaj eden med njimi, Osip Šest, zelo zgodaj povsem posvetil režiranju in tako je dobilo slovensko gledališče, kot pravi Moravec, »razgledanega, presenetljivo delavoljnega, okretnega, pa tudi prilagodljivega režiserja, prvega ,profesionalca'v tej stroki pri nas« (Slovenski režiserski 18).

Osamosvajanje režiserske stroke se je močno pospešilo v drugi polovici 20. stoletja, ko se je režiser poklicno že povsem ločil od igralca. Takrat je režiser odprl še eno »fronto«: začel je boj za pravico do lastne interpretacije uprizoritvenega besedila in je tako občasno prihajal navzkriž z dramatikom, kateremu je začel odžirati monopol nad avtorstvom. Nekateri dramatiki (ali njihovi dediči) se niso mogli sprijazniti z omejevanjem vpliva na uprizarjanje svojih besedil in s čedalje večjo interpretativno svobodo, ki so si jo jemali režiserji, zato so postali občasni spopadi med dramatiki in režiserji del gledališke folklore. Kot primer lahko navedem spor med Gregorjem Strnišo in Miletom Korunom zaradi uprizoritve Ljudožercev, najprej v sedemdesetih

$2 \mathrm{~V}$ času do začetka prve svetovne vojne so največ predstav režirali Anton Verovšek, Adolf Dobrovolný, Lev Dragutinović, Hinko Nučič, Milan Skrbinšek in Josip Povhe, poleg njih pa so nekaj predstav režirali tudi František Lier, Vilém Taborský, Jaroslav Tišinov, Rudolf Deyl, Ignacij Borštnik, Anton Cerar Danilo in njegova soproga Avgusta Danilova kot edina režiserka.

30 tem zgovorno priča tudi anekdota iz spominov Milana Skrbinška: »Režiser je bil samo vodja vaj, ki je skrbel zgolj za to, da so se vaje vršile, da so bili igralci tistega komada od začetka do konca vaje vedno vsi prisotni, pa se je zgodilo le redkokdaj, da bi kaj posegel vmes. Pri neki vaji sem na primer doživel to, da sta imela Avgusta Danilova in Verovšek sama daljši dialog, pa se je režiserju Danilu na nekem mestu le zdelo, da bi glede na igre obeh moral nekaj pripomniti, a ga je Danilova skrajno začudeno pogledala in ogorčeno dejala: ,Kaj ti pa je? Pusti naju vendar pri miru! To bova že sama napravila!' Prav tako se režiser ni smel vtikati v igralčevo oblikovanje monologa « (Skrbinšek, Gledališki mozaik 66). 
letih, ko je bil dramatik še živ, potem pa po njegovi smrti leta 1987, ko je Korunovi režiji tega besedila nasprotovala Strniševa vdova. Kako ostro in odklonilno je bilo Strniševo stališče do Korunove režije njegove igre, lepo ponazori mnenje Vena Tauferja, da bi tudi po svoji smrti, če bi le lahko, »Gregor Strniša prepovedal tudi samega Strnišo, če bi ga režiral Korun« (nav. po Milohnić, »Speculum mundi« 8). Razmerje med dramatikovo in režiserjevo integriteto je bilo v tem primeru še posebej zaostreno, saj je bil na eni strani avtor, ki je bil izrazito navezan na svoje besedilo (Strniša: »Glavno je, da mi bodo lepo govorili besedilo ...«), na drugi pa režiser, ki si je želel radikalno poseči v besedilo, da bi iz njega iztisnil čim več uprizoritvenega potenciala (Korun: »Ko smo prvič delali Žabe v Drami, sem natančno upošteval njegova scenska navodila. In ni šlo nikamor.«), zato je bil spor neizogiben (prim. prav tam 10). V današnjem času so avtorji besedil navadno pripravljeni priznati režiserju nekoliko več interpretativne svobode, čeprav se občasno še pojavljajo sporne situacije, ko se avtorji sklicujejo na določbo Zakona o avtorski in sorodnih pravicah, ki v 19. členu podeljuje izključno pravico avtorju, »da se upre skazitvi in vsakemu drugemu posegu v svoje delo ali vsaki uporabi svojega dela, če bi ti posegi ali ta uporaba lahko okrnili njegovo osebnost «. ${ }^{4}$

\section{Eksperimentiranje s skupinskim ustvarjanjem}

Kot izhaja iz dosedanje razprave, $\mathrm{v}$ slovenskem, evropskem in delno tudi svetovnem gledališču lahko spremljamo linijo osamosvajanja, profesionalizacije in individualizacije režijskega poklica. Po drugi strani pa se je najpozneje v šestdesetih letih prejšnjega stoletja (po nekaterih mnenjih, kot bomo videli v nadaljevanju, tudi prej) pojavil vzporedni tok, za katerega je značilno skupinsko ustvarjanje ali kot je Igor Lampret prevedel geslo »Création collective« v Pavisovem Gledališkem slovarju - »skupinska stvaritev«. Pavis razlaga, da je skupinska stvaritev »uprizoritev, ki je ne podpisuje en sam ustvarjalec (dramatik ali režiser), temveč skupina, ki jo je pripravila«. Eksperimentiranje s skupinskim ustvarjanjem v šestdesetih in sedemdesetih letih je bilo povezano s širšim družbenim vzdušjem, ki je spodbujalo ustvarjalnost posameznikov znotraj skupine. „Prav s pomočjo te skupine, « pravi Pavis, »naj bi presegli tudi ,tiranijo‘ avtorja in režiserja, ki sta nagnjena k centralizaciji vseh pristojnosti in odločanju o vseh estetskih in ideoloških vprašanjih « (Gledališki slovar 673). Pri tem ne gre le za estetska vprašanja, saj skupinsko ustvarjanje "politično sovpada z zahtevo po množični umetnosti in umetnosti za množice, po neposredni demokraciji in samoupravni produkciji skupine, « poudarja Pavis in kot

4 Novejši primer je spor med avtorico Anjo Golob in Slovenskim mladinskim gledališčem, ki se je moralo avtorici opravičiti s plačanim oglasom v medijih: „Slovensko mladinsko gledališče se opravičuje avtorici Anji Golob za skazitev njenega avtorskega dela, tj. odrske adaptacije otroške stripovske serije Ariol, ki jo je Slovensko mladinsko gledališče dne 19. 1.2019 pod naslovom ,Ariol: zaljubljen do ušes' in ,Ariol: popoldanske oslarije‘ v režiji Matjaža Pograjca bistveno spremenjeno uprizorilo na način, da uprizorjeno delo ni več ustrezalo vsebini in kvaliteti avtoričinega izvornega dela, zaradi česar se je bila Anja Golob zaradi zaščite svojega ugleda in dobrega imena od svojega avtorskega dela prisiljena javno distancirati« (Mladina, št. 7, 14. 2. 2020). 
paradigmatična primera tega procesa navede znameniti severnoameriški skupini The

Living Theatre in The Performance Group (674).

Tudi v Sloveniji lahko najdemo primere gledaliških skupin, ki so $\mathrm{v}$ tem času prakticirale podobne oblike skupinskega ustvarjanja, med njimi npr. Gledališče Pupilije Ferkeverk. Ko se je veliko pozneje spominjal svojega sodelovanja s Pupilčki ob koncu šestdesetih let, je Dušan Jovanović uporabil besede »klapa«, »grupa«, »pleme«, »bratovščina« ... Kolektivizem Pupilčkov ni bil »ne hierarhičen ne represiven, baziral je na participaciji«, tudi on kot režiser naj ne bi nastopal avtoritativno. »Ideje smo si, kot v igrah z žogo, podajali in jih razvijali v verižnih reakcijah, « se je spominjal Jovanović (70-71). Ko je pozneje nadaljeval režisersko kariero v poklicnih gledališčih, je zaman iskal ta kolektivni princip ustvarjanja: »Ansambel ni tovarišija, « saj v njem »vladajo stroga hierarhična pravila« (72). Še pred tem je v Gleju režiral Štihov Spomenik, ki ga je radikalno skrajšal (avtor temu ni nasprotoval), od dvanajstih igralcev na začetku procesa pa je do premiere ostala samo Jožica Avbelj, ki jo je spremljal glasbenik Matjaž Jarc. Študij predstave Spomenik G (črko g je dodal Štihovemu naslovu, »da bi povedal, kako je ta spomenik tudi naša, glejevska zgodba«) naj bi bil »štiri in pol mesece dolga kalvarija, « ki so jo lahko zaključili šele, ko so naredili »homogeno grupo, pa čeprav je ta grupa štela le enega člana« (75).

Prav v tem času, malo pred premiero Spomenika $G$, se je Lado Kralj, tudi sam soustanovitelj Gleja, vrnil iz ZDA, kjer je nekaj več kot leto nabiral izkušnje pri Richardu Schechnerju in The Performance Group. Kralj je sodelavcem v Gleju očital, da so pozabili na izvirne ideje in da reproducirajo strukturo gledališke institucije, zato je skupaj z nekaterimi študenti primerjalne književnosti, umetnostne zgodovine in gledališke akademije ustanovil novo gledališče v opuščeni pekarni, ki je gledališču dala ime. Ko se je v novejšem času v pogovoru s Primožem Jesenkom spominjal začetkov Pekarne, je Kralj izpostavil skupinski duh in svobodno izbiro pri odločitvah igralcev, kaj bo njihov prispevek k predstavi: »Ko je bil tekst izbran in predložen grupi, je ta odprto debatirala o tem, kako se bi ga dalo montirati ali kdo bo prevzel kateri delež [...]. Če igralec ni našel stika s svojim materialom, potem tega ni igral« (Jesenko 120). Ta skupinski duh se je začel krhati, ko se je - po Kraljevi oceni nekako po peti predstavi - skupina pogreznila $\mathrm{v}$ obsesivno ukvarjanje $\mathrm{z}$ individualnimi psihičnimi frustracijami in je tako gledališki kolektiv postajal čedalje bolj podoben terapevtskemu krožku. »Ob tej kleči se je takrat razbila tudi marsikatera ameriška off off grupa « (Kralj 8), kajti skupinsko ustvarjanje v gledališču bi vendarle moralo biti nekaj več kot spogledovanje s psihično rehabilitacijo, ki je vrh vsega še povsem spontana in nestrokovna. Ko so se na to konceptualno krizo cepile še finančne težave, je bila usoda Pekarne dokončno zapečatena. 
Pojav skupinskega ustvarjanja, tudi kolektivne režije, torej navadno povezujemo s šestdesetimi leti, z dogajanjem v takratnem gledališču in s širšimi, političnimi procesi v družbi, zlasti s študentskim gibanjem, hipijevskim načinom življenja, komunami itn. Skupina raziskovalcev, ki zadnjih deset let preučuje prav skupinsko ustvarjanje v gledališču 20. stoletja, pa ugotavlja, da ne gre za eksces, temveč za vzporedni tok, ki je spremljal dominantno režijsko gledališče že od samega začetka. Do zdaj so izdali več zbornikov, ki sta jih uredila Kathryn Mederos Syssoyeva in Scott Proudfit (A History of Collective Creation, 2013; Collective Creation in Contemporary Performance, 2013; Women, Collective Creation and Devised Performance, 2016), v katerih zagovarjajo tezo o »treh valovih « skupinskega ustvarjanja v gledališču 20. stoletja: najprej v prvi polovici stoletja (npr. skupinsko raziskovanje in ustvarjanje v studiih in laboratorijih, ki so jih ustanovili Mejerhold, Copeau, Saint-Denis in drugi), potem od sredine petdesetih do začetka osemdesetih let (npr. The Living Theatre, The Performance Group, Wooster Group in podobne skupine, prav tako raziskovalni centri, npr. Mednarodni center za raziskovanje gledališča, ki ga je v Parizu ustanovil Peter Brook, Mednarodna šola gledališke antropologije, ki jo je na Danskem ustanovil Eugenio Barba itn.) in na koncu še tretji val, ki se začne v osemdesetih letih in traja še danes.

\section{Skupinsko in snovalno gledališče}

$\mathrm{V}$ novejšem času, zlasti $\mathrm{v}$ zadnjih dveh desetletjih, se je $\mathrm{v}$ anglosaških razpravah uveljavilo poimenovanje devised theatre (snovalno gledališče), ${ }^{5}$ ki se navadno nanaša na nastajanje predstave ex nihilo, torej brez uporabe vnaprej napisanega dramskega besedila, ampak ga nekateri avtorji povezujejo tudi s skupinskim načinom ustvarjanja. V vplivni monografski študiji Devising Performance: A Critical History (2005) Deirdre Heddon in Jane Milling pripisujeta ta način ustvarjanja »tistim gledališkim skupinam, ki uporabljajo izraza 'snovalno' ali 'skupinsko' ustvarjanje, da opišejo način dela, pri katerem ni nobene predloge - ne dramskega besedila ne uprizoritvenega scenarija preden skupina ustvari predstavo« (3). Očitno ta opredelitev skuša enačiti skupinsko (ali sodelovalno) s snovalnim načinom ustvarjanja, čeprav ni nujno, da gre za enake prakse. Hipotetično sta lahko tako skupinska kot snovalna pristopa značilna za eksperimentalne in neodvisne gledališke skupine iz poznih šestdesetih let, vendar nikakor ne drži, da so predstave teh skupin vedno nastajale ex nihilo, saj so mnoge izhajale iz že napisanih - sodobnih ali klasičnih - dramskih besedil. Čeprav je videti,

5 To je trenutno najnovejša prevajalska rešitev, ki sta jo predlagali Zala Dobovšek in Maja Šorli v prispevku »Kralj Ubu šok snovalnega gledališča v nacionalni instituciji« (2016). Pred tem je Eva Mahkovic, prevajalka knjige Cathy Turner in Synne K. Behrndt Dramaturgija in predstava (2011), poskusila s prevodom »raziskovalno gledališče», Jan Jona Javoršek, prevajalec Pavisove knjige Sodobna režija (2012), pa je predlagal »iznajdeno gledališče« in obenem v prevajalčevi opombi pod črto navedel, poleg že omenjene možnosti »raziskovalno gledališče«, še "procesno gledališče« (337). Gledališki terminološki slovar, ki je nekaj let starejši (2007), še ne vsebuje nobenega od teh izrazov, pozna pa »avtorsko gledališče«, ki ga primarno definira kot "gledališče, v katerem je avtor dramskega besedila tudi režiser ali igralec in uveljavlja svojo poetiko«, sekundarno pa kot »gledališče, ki pri uprizarjanju ustvarja, uveljavlja svojo poetiko« (33). 
da se je v sodobnih uprizoritvenih praksah okrepil snovalni pristop in da je ta modus operandi izpodrinil nekdanje poudarjeno horizontalno, egalitarno naravnano skupinsko ustvarjanje, nikakor ne gre za pojava, ki bi ju bilo mogoče enačiti. Kot opozori Patrice Pavis v Sodobni režiji, »kolektivno ustvarjanje je danes mnogo več kakor devised theatre, torej gledališče imaginacije nekega kolektiva, subjekta brez usmeritve, ki torej dela na osnovi tega, kar je mogoče najti v skupini, in ne na osnovi vnaprejšnje zamisli« (345). Na to opozori tudi Kathryn Mederos Syssoyeva v uvodnem poglavju knjige Collective Creation in Contemporary Performance, ko razlaga, da je $\mathrm{z}$ uporabo metodologije, ki jo je razvila njena raziskovalna skupina, snovalni model »hitro izginil s horizonta kot odločujoči dejavnik« (5), sami pa so se osredotočili na skupinsko ustvarjanje kot uprizoritveno prakso, ki je lahko v različnih razmerjih do uprizoritvenega besedila. Z drugimi besedami, da lahko določeno uprizoritveno prakso označimo kot skupinsko ustvarjanje, ni nujno, da besedilo (če sploh obstaja) nastane v procesu nastajanja predstave, čeprav je res, da se v sodobnem gledališču povečuje delež predstav, ki niso uprizoritve obstoječih, že napisanih dramskih besedil.

Na raznovrstne pristope in možne povezave med skupinskim in snovalnim v drugi polovici 20. stoletja opozori Višnja Kačić Rogošić v novejši monografski študiji Skupno osmišljeno kazalište (2017), v kateri, med drugim, pregledno predstavi poskuse iskanja ustreznic za angleški izraz devised v raznih jezikih, npr. v češčini (autorské divadlo), srbščini (građenje pozorišta), hrvaščini (osmišljeno kazalište), slovenščini (snovalno gledališče) itn. Avtorica opozori tudi na nekatere druge različice, ki se pojavljajo v hrvaških virih, npr. od kolektivne režije (zlasti v sedemdesetih letih) in avtorskega gledališča (izraz, ki se pogosto uporablja tudi v slovenskem gledališču) do razvojnega gledališča (s katerim način ustvarjanja skupine Bacači sjenki označuje njen soustanovitelj Boris Bakal) in kolaborativnega gledališča. V anglosaškem prostoru se pojavljajo tudi sintagme, ki povezujejo skupinski in snovalni princip, npr. group devised theatre, collaboratively devised theatre, ensemble-based work ipd. Kanadski teatrolog Bruce Barton meni, da se v teh pojmovnih konstruktih collective nanaša na »skupni namen in motivacijo, ideologijo « skupine, collaboration na »okvir in strukturo, kontekst«, ki si jih skupina sama določi, devising pa na »sprejete strategije in pravila, proces« (Barton ix; prim. tudi Kačić Rogošić 13). Tudi Višnja Kačić Rogošić se je odločila za povezavo dveh ključnih pojmov, torej skupinsko in snovalno, da je lahko metodološko zamejila raziskovalno polje, in se je v osrednjem delu študije poglobila v primere »skupnega snovalnega gledališča« na Hrvaškem od šestdesetih let do danes. Specifičnost tega gledališča avtorica vidi v »proizvajanju večine materiala predstave skozi skupinsko delo vseh članov gledališke skupine tekom vaj« (19). 
Tudi v sodobnem slovenskem gledališču je vse več predstav, kjer vnaprej napisano dramsko besedilo ni ključno za končni produkt ustvarjalnega procesa. Dva najpogosteje uporabljana izraza, ki označujeta to vrsto predstav, sta "po motivih« in »avtorski projekt«.

Predstave, ki nastanejo po motivih, načeloma temeljijo na obstoječih igrah ali drugih literarnih zvrsteh, vendar jih ustvarjalci uporabljajo le kot izhodišče za povsem novo kompozicijo besedila predstave. V zadnjih petih, šestih letih je npr. režiser Jernej Lorenci, ki se je obdal s skupino rednih sodelavcev, uprizoril več predstav po motivih znanih dramskih besedil: Učene ženske po motivih Molièrovih Učenih žensk (SLG Celje in MG Ptuj, 2015), Kralj Ubu po motivih Kralja Ubuja (SNG Drama Ljubljana, 2016), Sen kresne noči (MGL, 2017), Škofjeloški pasijon (PG Kranj in MG Ptuj, 2020) itn. Tik pred izbruhom epidemije kovida 19 je nastala uprizoritev Sedem vprašanj o sreči: gledališko potovanje po motivih Modre ptice Mauricea Maeterlincka (Lutkovno gledališče Ljubljana in SMG, 2020) v režiji Tomija Janežiča. Sicer pa ni nujno, da tovrstne predstave nastanejo po motivih dramskih besedil; tako je npr. Žiga Divjak režiral Hlapca Jerneja in njegovo pravico (Cankarjev dom in AGRFT, 2018) po motivih znamenite Cankarjeve povesti, predstava Do zadnjega diha: Zdaj (MGL, 2014), ki jo je režiral Jaša Koceli, je nastala po motivih Godardovega filma Do zadnjega diha, Matjaž Berger je režiral več predstav v Anton Podbevšek Teatru po motivih filozofskih besedil ipd.

Za avtorske projekte je značilno, da predstave nastajajo na podlagi individualnih ali skupinskih prispevkov $\mathrm{v}$ ustvarjalnem procesu, kar ima za posledico popolnoma novo uprizoritveno besedilo. Nekaj odmevnih avtorskih projektov je nastalo pod režijskim vodstvom Oliverja Frljića, npr. Preklet naj bo izdajalec svoje domovine! (SMG, 2010), 25.671 (PG Kranj, 2013), Kompleks Ristić (SMG in koproducenti, 2015), Naše nasilje in vaše nasilje (SMG, 2016). Med avtorske projekte bi lahko uvrstili tudi Ljubezen do bližnjega (SNG Nova Gorica, 2016) in Stenico (PG Kranj in MG Ptuj, 2017) v režiji Jerneja Lorencija, nekatere predstave v režiji Žige Divjaka, npr. 6 (SMG in Maska, 2018), Sedem dni (MGL, 2019) in Gejm (SMG, 2020), vsaj dva projekta v režiji Janeza Janše - Zraka! (Maska in SMG, 2015) in Republika Slovenija (SMG in Maska, 2016; avtorstvo te predstave je sicer "uradno anonimno in kolektivno) in še razne druge uprizoritve. Poseben primer bi lahko bila predstava še ni naslova (SMG, 2018), ki je nastajala postopoma, med celotno gledališko sezono, najprej na način snovalnega gledališča, ko so imeli ustvarjalci le izhodiščni motiv Don Juana in so razvijali lastne zgodbe, vzporedno pa je nastalo besedilo Simone Semenič, ki ga je režiser Tomi Janežič tako rekoč »vdelal« v uprizoritveni material, ki je že nastal na vajah.

Čeprav izraza "po motivih « in »avtorski projekt « nista sinonima in ju ni mogoče enačiti (kljub občasnim prekrivanjem, kot je npr. Lorencijev Sen kresne noči s podnaslovom 
»avtorski projekt po igri Williama Shakespeara«), oba implicirata snovalni tip gledališča. Po drugi strani pa to ne pomeni, da so uprizoritve po motivih ali avtorski projekti nujno tudi skupinske stvaritve, saj lahko nastanejo tudi na način tradicionalne delitve dela $\mathrm{v}$ ustvarjalnem procesu $\mathrm{z}$ režiserjem kot avtoritativnim vodjo in glavnim avtorjem predstave. Ker ni nujno, da sta v procesu nastajanja predstave uporabljena oba principa, torej skupinsko in snovalno ustvarjanje, se raziskovalec uprizoritvenih praks - zlasti takrat, kadar nima neposrednega vpogleda v uprizoritvene postopke in procedure - sooča s težavno nalogo, da prepozna in ustrezno ovrednoti delež enega in drugega $v$ končnem produktu tega procesa, torej v javni uprizoritvi.

Premislek o razmerju med skupinskim in snovalnim, do katerega me je pripeljala razprava o položaju režiserja (deloma tudi dramatika) v gledališču 20. in začetka 21. stoletja, zdaj lahko zgostim v ugotovitvi, da je za skupinsko gledališče konstitutivno specifično razmerje med ustvarjalno skupino in pozicijo režiserja (od vzpostavitve funkcije režiserja in njegove profesionalizacije do danes to razmerje niha med avtoritarnim in demokratičnim, hierarhičnim in egalitarnim, vertikalnim in horizontalnim), medtem ko je za snovalno gledališče ključno razmerje med ustvarjalno skupino in pozicijo dramatika (od uprizarjanja dramskega besedila kot relativno avtonomne literarne umetnine do uprizoritvenega besedila, ki nastane kot integralni del procesa, vaj, igralskih improvizacij itn., pri čemer sicer lahko sodeluje tudi dramatik, vendar ne kot izključni avtor dramskega besedila). Ta temeljna razmerja postanejo še nekoliko kompleksnejša in zato tudi težje razpoznavna, če se $\mathrm{v}$ ustvarjalnem procesu prepletejo $\mathrm{v}$ večplastno teksturo različnih silnic, ki nastajajo $\mathrm{v}$ trikotniku med dramatikom, režiserjem in ustvarjalno skupino. Ta kompleksna struktura, v kateri so funkcije pogosto tudi zabrisane, saj ni več nujno, da so dominantne pozicije vnaprej določene, in prihaja tudi do premikov dominant med temi funkcijami, je produkcijsko okolje, v katerem nastaja skupinsko snovalno gledališče, kot ga imenuje Višnja Kačić Rogošić. Krepitev te paradigme prispeva k raziskovalni naravnanosti ustvarjalcev, ne le režiserja in ustvarjalne skupine, ki naj bi relativno enakovredno sodelovala pri avtorstvu predstave, temveč tudi dramatika, vsaj takrat, kadar je neposredno vključen v proces nastajanja predstave. Če je bila za gledališče v prvi polovici 20. stoletja značilna postopna specializacija poklicev, se je $\mathrm{v}$ drugi polovici 20. in v začetku 21. stoletja zgodil premik k hibridnim modelom in številnim kombinacijam, ki bogatijo spekter možnih simbiotičnih učinkov med nekoč relativno ostro razmejenimi funkcijami v okviru prevladujočega modela ustvarjalnega procesa v meščanskem gledališču. V sodobnem gledališču je tako čedalje pogostejše skupinsko avtorstvo predstave, igralci in drugi soustvarjalci predstave prispevajo lastno uprizoritveno besedilo ali dopolnjujejo obstoječe, režiserji se ponovno pojavljajo na odru, prav tako nekateri izkušenejši igralci občasno prevzemajo funkcijo režiserja (tako kot je že bilo v navadi ob koncu 19. in v začetku 20. stoletja), dramatiki prispevajo besedila sproti, med nastajanjem predstave, v kateri se lahko tudi sami 
pojavijo ali pa, kot npr. v predstavi še ni naslova, vsaj slišimo njihov glas ipd. Ker se je v 20. stoletju režiser vzpostavil kot vodilna figura v ustvarjalnem procesu, so na pojav skupinskega (in) snovalnega gledališča pomembno vplivale spremembe njegove pozicije v tradicionalnem modelu gledališke hierarhije. Spremembe položaja sodobnih režiserjev so prinesle tudi več njihove (samo)refleksije, saj so poleg teoretikov (na nekatere sem že opozoril), v novejšem času tudi številni režiserji premišljevali o teh procesih v sodobnem gledališču. Zanimivo je, da se nekateri med njimi ne strinjajo s podmeno, da je režijsko gledališče okrepilo položaj režiserja v razmerju do dramatika, kot ta proces režiserjeve emancipacije v 20. stoletju razlagajo Pavis, Badiou in drugi vidnejši teoretiki. Kot primer lahko omenim Oliverja Frljića, ki meni, da je v dramskem gledališču režiser tako rekoč neizogibno v funkciji »interpreta dramskega avtorja«. Celo v režijskem gledališču, ko so se režiserji poskušali oddaljiti od te funkcije, se je niso mogli povsem znebiti: »Ko je zasedel pozicijo dramskega avtorja, je režiser na videz opustil klasično derridajevsko shemo teološke scene, vendar jo je s tem v bistvu samo okrepil, saj logocentrični model tudi v tem primeru ostaja dominanten « (75). Frljićeve predstave navadno uvrščamo v paradigmo političnega gledališča, zato bo morda videti nekoliko nenavadna njegova trditev, da se je v teh predstavah ukvarjal predvsem z vprašanjem režiserja: »Njihova političnost, natančneje preizpraševanje političnega $v$ gledališču in kaj bi lahko bilo danes politično gledališče, je bila le predloga za premislek o poziciji in funkciji režiserja« (prav tam).

V novejšem času se pojavljajo tudi radikalne ideje o tako imenovanem heterarhičnem režiserju, s katerim naj bi se zgodil premik od hierarhičnega modela gledališkega kolektiva z režiserjem kot avtoritativnim gurujem k samoorganizirani ustvarjalni skupini, v kateri se od režiserja ne pričakuje vodenje, temveč spodbujanje in opolnomočenje sodelavcev (prim. Radosavljević 248). Če je v večjem delu 20. stoletja prevladovalo režijsko gledališče, bi se lahko vprašali, ali morda krepitev skupnega ustvarjanja ob koncu 20. in v začetku 21. stoletja, ki časovno sovpada s pojavom postdramskega gledališča, oznanja prehod na postrežijsko gledališče? ${ }^{6}$ To vprašanje odpira obsežno in kompleksno temo, ki bi si nemara zaslužila obravnavo v posebnem članku, zato se bom ob tej priliki omejil le na omembo nekaterih skupin, ki raziskujejo možnosti drugačnega načina režiranja s skupinskim pristopom. Med zanimivejšimi je gotovo nemška skupina She She Pop, njene članice so skoraj izključno ženske, ki svoje predstave ustvarjajo kolektivno, ne da bi se pri tem ločevale po funkcijah igralk, režiserk, dramaturginj itn. V slovenskem prostoru podobne prijeme preizkuša Beton Ltd., skupina performerjev (Primož Bezjak, Branko Jordan, Katarina Stegnar), ki prisegajo na načelo emancipiranega igralca in režije brez režiserja, prevzemajo polno

6 Oznako »postrežijsko gledališče« je že pred desetimi leti uporabila urednica kar dveh tematskih številk beograjske gledališke revije Teatron (»Postrediteljsko pozorište i/ili nove rediteljske prakse«) Aleksandra Jovićević. V uvodnem članku prve tematske številke je - verjetno po vzoru koncepta »ne več dramskega gledališkega besedila« Gerde Poschmann - predlagala tudi sintagmo »ne več režijsko gledališče«, v katerem, kot pravi, »izginjajo tradicionalne vloge in razmerja« ter prihaja do »izenačevanja vseh ustvarjalcev, ki od začetka delajo na skupnem konceptu« (10). 
odgovornost za svoje predstave in tako dekonstruirajo pojem režije v fluidni in obenem kolektivni označevalec. ${ }^{7}$ Nekoliko drugačen je primer skupine Rimini Protokoll, ki so jo leta 2000 ustanovili Helgard Haug, Stefan Kaegi in Daniel Wetzel. Njeni člani lahko ustvarjajo skupaj ali ločeno, pogosto na način snovalnega gledališča, in pri tem sledijo zgodbam in izkušnjam navadnih ljudi, ki v njihovih predstavah nastopajo kot amaterski igralci oziroma, kot jih sami imenujejo, »eksperti vsakdanjega življenja«. Za Rimini Protokoll je ključnega pomena prav ta košček realnosti, ki ga prinesejo na oder neizšolani igralci, ko govorijo o sebi, svojem delu, življenju, družini itn. »Gledališče preizkušamo kot model izkušnje in ne reprezentacije, « pravi Daniel Wetzel (nav. po Milohnić, »Performing Labour« 76). Prav zato, ker »eksperti vsakdanjega življenja« ne predstavljajo dramskih likov, temveč le sebe in svoje vsakdanje izkušnje, jih Rimini Protokoll šteje za soavtorje uprizoritev. Po besedah Stefana Kaegija njihovo skupino zanima raziskovanje modelov skupnega ustvarjanja in načinov uravnavanja delovnih procesov v gledališču, saj ko so-ustvarjaš v skupinskem tipu gledališča, »se moraš vedno vprašati, kaj je mogoče narediti skupaj, in moraš delati v skladu z odločitvami, ki jih sprejmeš skupaj« (nav. po Boenisch 111).

\section{Ustvarjalna skupina kot kolektivna subjektiviteta}

Tako kot je besedilo v postdramskem gledališču le eden izmed mnogih drugih elementov uprizoritve, je v skupinskem gledališču režija le ena izmed ustvarjalnih plasti predstave. Če smo pripravljeni sprejeti to enačbo, ni nobenega razloga, da bi v sodobnem, postdramskem gledališču dramatik ohranjal monopol nad avtorstvom besedila, režiser pa se ponašal z avtorstvom uprizoritve kot celote. Ko v Gledališkem slovarju razlaga pomen skupinske stvaritve, Pavis spomni, da je že Brecht skupinsko delo v gledališču opredelil kot "posploševanje znanja«, kar naj bi po njegovem izhajalo iz 70. paragrafa Brechtovega Malega organona za gledališče: »Zgodbo podaja, razgrinja in postavlja na ogled gledališče kot celota, se pravi igralci, inscenatorji, maskerji, kostumografi, skladatelji in koreografi. Vsi ti združujejo svoje umetnosti v skupni zamisli in se pri tem kajpak ne odpovedujejo svoji samostojnosti (Brecht 391). Pavis naprej razlaga, da bi to skupinsko znanje »lahko razumeli kot vzpostavitev diskurza označevalnih sistemov na odru, ko režija ni več govor enega samega avtorja (bodisi dramatika, režiserja ali igralca), temveč bolj ali manj vidna sled, ki jo ustvarja skupinski govor« (674-675).

Pavisova razlaga skupinske stvaritve $\mathrm{z}$ vpeljavo Brechtovega "posploševanja znanja« kot oblike produkcije, ki bi lahko postal (ali bi celo moral postati) dominantni način produkcije v gledališču »znanstvene dobe«, je po mojem mnenju nenavadna in

70 temeljnih načelih delovanja skupine Beton Ltd. je govoril njen član Branko Jordan 8. oktobra 2020 v navdihnjeni predstavitvi na simpoziju Skupnost deluje. 
hkrati spoznavno spodbudna zgostitev dveh pomembnih konceptov iz zakladnice materialistične misli: Marxovega »občega intelekta (general intellect) in Bahtinove "polifonije«. Obči intelekt se skozi razvoj znanosti opredmeti v fiksnem kapitalu, torej v strojih, kar je veljalo v Marxovem času industrijskega kapitalizma in v osnovi velja tudi danes, v postfordističnem kapitalizmu, vendar, kot razlaga Paolo Virno v Slovnici mnoštva, obstaja tudi kot atribut živega dela, kot »abstraktno mišljenje, ki je postalo steber družbene proizvodnje« (49) in se »danes kaže predvsem kot komunikacija, abstrakcija, samorefleksija živih subjektov« (50). Z drugimi besedami, občega intelekta »ni več mogoče ločiti od kooperacije, od skupnega delovanja živega dela, od komunikacijske sposobnosti individuov« (51). Če si lahko dovolim nekoliko metaforično ali celo poetično branje Marxovega koncepta, bi lahko Brechtovo "posploševanje znanja« označil za svojevrstni obči gledališki intelekt, skupni kvantum gledališkega znanja in ustvarjanja, ki se utelesi v skupinskem ustvarjanju postdramskega gledališča in tako ustvarjalna skupina, gledališki kolektiv, privzame obliko kolektivne subjektivitete. Pavisova »vzpostavitev diskurza označevalnih sistemov na odru « kot »sled, ki jo ustvarja skupinski govor," pa je manifestacija Bahtinove polifonije $\mathrm{v}$ procesu produkcije skupinske stvaritve postdramskega gledališča. K temu bi lahko dodal, da skupinsko ustvarjanje prevaja abstraktne ideje, ki jih generira polifoničnost skupinskega mišljenja, v »realne abstrakcije« (še en izraz iz Marxovega pojmovnega registra), da torej abstraktne ideje in misli prevede $\mathrm{v}$ fizično - telesno in predmetno - realnost gledališke uprizoritve.

Premislek o položaju režiserja $\mathrm{v}$ razmerju do drugih ustvarjalcev $\mathrm{v}$ gledališču 20. stoletja in danes, ko se krepijo skupinske in snovalne oblike gledaliških praks, odpira vznemirljiva vprašanja; $v$ tem članku sem se dotaknil le nekaterih izmed njih. Analiza uprizoritve Kralja Ubuja z vidika snovalnega gledališča, ki sta jo razvili Maja Šorli in Zala Dobovšek, je gotovo ena izmed pomembnejših študij primera z vidika snovalnega gledališča v slovenski gledališki teoriji, a za tehtnejši spoprijem $\mathrm{s}$ tem teoretskim poljem bi potrebovali še veliko več podobnih prispevkov. Zato bi k temu, kar je že ugotovil Pavis za francosko in evropsko gledališče, da namreč »nimamo zgodovinskega pregleda stvaritev, ki so nastale skupinsko kot plod dela gledaliških skupin, " in bo zato treba "preučevanje režije in režiserjevih odločitev podpreti dopolniti in okrepiti - z zavestjo o skupinskem delu« (345), lahko dodal le to, da ta naloga čaka tudi raziskovalce slovenskega gledališča. 
Badiou, Alain. 20. stoletje. Društvo za teoretsko psihoanalizo, 2005.

Barba, Eugenio. Papirnati kanu. MGL, 2005.

Barton, Bruce, urednik. Collective Creation, Collaboration and Devising. Playwrights Canada Press, 2008.

Boenisch, Peter M. »Other People Live: Rimini Protokoll and their ,Theatre of Experts « Contemporary Theatre Review, letn. 18, št. 1, 2008, str. 107-113.

Bradby, David, in David Williams. Directors' Theatre. St. Martin's Press, 1988.

Braun, Edward. The Director and the Stage. Methuen, 1982.

Brecht, Bertolt. »Mali organon za gledališče«. Umetnikova pot. Cankarjeva založba, 1987, str. 371-398.

Debevec, Ciril. »Vprašanje režiserjev v ljubljanski drami«. Svobodne roke. Antologija teoretske misli o slovenskem gledališču (1899-1979), uredila Blaž Lukan in Primož Jesenko. UL AGRFT in Maska, 2012, str. 107-116.

Frljić, Oliver. »Čemu režiser?«. Teatron, letn. 35, št. 152-153, 2010, str. 75-78.

Gledališki terminološki slovar, uredila Marjeta Humar et al. ZRC SAZU, 2007.

Heddon, Deirdre, in Jane Milling. Devising Performance: A Critical History. Palgrave Macmillan, 2006.

Jovanović, Dušan. Paberki. MGL, 1996.

Jovićević, Aleksandra. »Uvod u temu broja«. Teatron, letn. 35, št. 150-151, 2010, str. 9-10.

Jesenko, Primož. »Teater je lahko zelo drugačen od tega, kar si človek pod tem pojmom predstavlja. Pogovor z Ladom Kraljem«. Prišli so Pupilčki - 40 let Gledališča Pupilije Ferkeverk, uredila Aldo Milohnić in Ivo Svetina. Maska in Slovenski gledališki muzej, 2009, str. 111-131.

Kačić Rogošić, Višnja. Skupno osmišljeno kazalište. Hrvatski centar ITI, 2017.

Koter, Darja. »Glasbeno-gledališka režija na Slovenskem: od diletantizma Dramatičnega društva do profesionalizacije v Deželnem gledališču«. Muzikološki zbornik, letn. 46, št. 1, 2010, str. 57-69.

Kralj, Lado. »Hipijevsko, čutno, razpuščeno«. 20 let EG Glej. EG Glej, 1990, str. 6-8.

Milohnić, Aldo. »Speculum mundi Gregorja Strniše«. Gledališki list Koreodrame Ljubljana, januar 1993, str. 8-13.

-. »Performing Labour Relations in the Age of Austerity«. Performance Research, letn. 17, št. 6, 2012, str. 72-79. 
Moravec, Dušan. Slovensko gledališče Cankarjeve dobe (1892-1918). Cankarjeva založba, 1974.

—. Slovenski režiserski kvartet (z gostom). Slovenski gledališki in filmski muzej, 1996. Pavis, Patrice. Gledališki slovar. MGL, 1997.

-. Sodobna režija. MGL, 2012.

Radosavljević, Duška. »The Heterarchical Director: A Model of Autorship of the Twenty-First Century«. Directors' Theatre, uredil Peter M. Boenisch. Red Globe Press, 2020, str. 247-268.

Repertoar slovenskih gledališč 1867-1967, uredili Dušan Moravec et al. Slovenski gledališki muzej, 1967.

Senker, Boris. Redateljsko kazalište. CKD SSO Zagreb, 1977.

Skrbinšek, Milan. »Moderna režija«. Svobodne roke. Antologija teoretske misli o slovenskem gledališču (1899-1979), uredila Blaž Lukan in Primož Jesenko. UL AGRFT in Maska, 2012, str. 97-106.

—. Gledališki mozaik. 1. zvezek. MGL, 1963.

Šorli, Maja, in Zala Dobovšek. »Kralj Ubu - šok snovalnega gledališča v nacionalni instituciji . Amfiteater, letn. 4, št. 2, 2016, str. 14-32.

Syssoyeva, Kathryn Mederos, in Scott Proudfit. A History of Collective Creation. Palgrave Macmillan, 2013.

-. Collective Creation in Contemporary Performance. Palgrave Macmillan, 2013.

-. Women, Collective Creation and Devised Performance. Palgrave Macmillan, 2016.

Turner, Cathy in Synne K. Behrndt. Dramaturgija in predstava. MGL, 2011.

Virno, Paolo. Slovnica mnoštva. Krt, 2003. 